\title{
Results of vitrectomy performed at the time of phacoemulsification complicated by intravitreal lens fragments
}

\author{
Toshiyuki Kageyama, Masahiko Ayaki, Miki Ogasawara, Chihiro Asahiro, Shigeo Yaguchi
}

\begin{abstract}
Aim-To evaluate outcome of vitrectomy performed at the time of phacoemulsification complicated by intravitreal lens material.

Methods-Clinical records associated with consecutive 8536 phacoemulsification procedures were reviewed retrospectively. Results-17 $(0.20 \%)$ eyes had a posterior capsule rupture with retained lens material in the vitreous cavity that required vitrectomy. Final visual acuity was 0.5 or better in 14 eyes $(82 \%)$ and 0.4 to 0.1 in three eyes $(18 \%)$. Retinal detachment occurred in one eye during vitrectomy and two after the surgery. Cystoid macular oedema was observed in two eyes and none developed glaucoma. The corneal endothelial cell loss was 5.7\% (SD $6.8 \%$ ) $(n=15)$ at 3-6 months postoperatively. Conclusions-Combined vitrectomy and intraocular lens implantation at the time of phacoemulsification complicated by intravitreal lens material is an option to be considered to reduce the risk of postoperative complications including secondary glaucoma and corneal endothelial cell damage.
\end{abstract}

(Br f Ophthalmol 2001;85:1038-1040)

Dislocation of crystalline lens fragments into the vitreous cavity is an uncommon but potentially serious complication of cataract surgery. It can lead to marked intraocular inflammation resulting in cystoid macular oedema, vitreous opacification, glaucoma, and retinal detachment. ${ }^{1-6}$ For the purpose of reducing the further ocular damage, since 1992 we have routinely converted to three port vitrectomy in such case.

The first purpose of present study was to estimate the incidence of complicated phacoemulsification and aspiration (PEA) which needed vitrectomy to remove lens fragments in the vitreous; secondly, to evaluate intraoperative and postoperative complications and visual outcome after the procedure.

\section{Patients and methods}

We retrospectively reviewed the operative records of consecutive patients who underwent PEA from 1 June 1992 to 31 December 1999 at University of Showa, Fujigaoka Hospital, using computerised electronic databases. A total of 8536 PEA procedures were performed during the study period and $17(0.20 \%)$ were combined with vitrectomy for removal of lens material. All eyes had a large fragment of lens material in the vitreous cavity at least one third the size of the nucleus. A total of 7295 surgeries were performed by 11 senior surgeons who were very experienced in vitrectomy. Others were by 21 ophthalmological trainees. Surgical procedures of vitrectomy included three port pars plana vitrectomy, three port pars plana vitrectomy with phacofragmentation, or three port limbal based vitrectomy. In the case of trainee operators, vitrectomy was performed by the senior surgeon who was to be available any time in the operating theatre.

The imaging of the corneal endothelium was used for detailed evaluation of surgical intervention. The images were recorded with a specular microscope (SP-8000, Konan Co, Hyogo, Japan), and the density of endothelial cells was analysed both before and 3-6 months after the operation. We compared the results of the study group with that of control cases, 115 consecutive patients who underwent PEA only. The Mann-Whitney U test was used for statistical analysis.

\section{Results}

Seventeen eyes undergoing PEA followed by vitrectomy for intravitreal lens material were entered into the study. Twelve $(0.16 \%)$ of 7295 PEA were by senior surgeons, and five $(0.40 \%)$ of 1241 were by ophthalmological trainees. Clinical features and details of each case are summarised in Table 1 . The average age was 71 years (range 49-90) and the mean follow up period was 11 months (range 3-40). Three port pars plana vitrectomy was performed in 12 patients $(71 \%)$ and three port limbal based vitrectomy in five $(29 \%)$. A posterior chamber intraocular lens (IOL) was implanted primarily in 16 eyes (94\%). Intraoperative complications - that is, iatrogenic retinal tear, occurred in two eyes (12\%), proceeding to retinal detachment in one case (case 5).

Postoperative complications occurred in six eyes $(35 \%)$ (Table 1$)$. Two eyes developed retinal detachment, one (case 7 ) at 2 months after operation and the other (case 8) at 12 months. Although retinal reattachment surgery was successful in both cases, visual acuity worsened in patient 8 as a result of previous macular detachment and proliferative vitreoretinopathy. Cystoid macular oedema was observed in two eyes (cases 14 and 16). Both failed to achieve improvement of visual acuity. One eye (case 15) had IOL dislocation 4 months after the operation, requiring scleral fixation of the IOL. A slight elevation of intraocular pressure up to $27 \mathrm{~mm} \mathrm{Hg}$ occurred in two eyes (cases 5 and 
Table 1 Preoperative data and intraoperative and postoperative complications for eyes with intravitreal lens materials

\begin{tabular}{|c|c|c|c|c|c|c|c|c|}
\hline Case & Age/sex & $\begin{array}{l}\text { Preoperative } \\
\text { visual acuity }\end{array}$ & $\begin{array}{l}\text { Final visual } \\
\text { acuity }^{*}\end{array}$ & $\begin{array}{l}\text { Preoperative ocular } \\
\text { comorbidity }\end{array}$ & $\begin{array}{l}\text { Dislocated lens } \\
\text { material }\end{array}$ & Lens removal method & $\begin{array}{l}\text { IOL } \\
\text { implantation }\end{array}$ & $\begin{array}{l}\text { Intraoperative and } \\
\text { postoperative complications }\end{array}$ \\
\hline 1 & $72 / \mathrm{M}$ & 0.3 & 0.6 & & Nucleus & PPV & Suture & \\
\hline 2 & $66 / F$ & 0.2 & 1.0 & & Cortex & PPV & Insertion & \\
\hline 3 & $75 / \mathrm{F}$ & 0.06 & 1.2 & & Cortex & LV & Insertion & \\
\hline 4 & $61 / \mathrm{F}$ & 0.08 & 0.9 & Posterior lenticonus & Nucleus & PPV & Insertion & Retinal tear† \\
\hline 5 & $90 / \mathrm{M}$ & 0.01 & 0.6 & & Nucleus & PPV, Fragmatome & - & RD $†$, OHT $\ddagger$ \\
\hline 6 & $82 / \mathrm{F}$ & 0.4 & 1.0 & DMR & Nucleus & PPV, Fragmatome & Suture & \\
\hline 7 & $58 / \mathrm{M}$ & 0.4 & 1.0 & Posterior lenticonus & Nucleus & PPV & Insertion & $\mathrm{RD} \ddagger$ \\
\hline 8 & $80 / \mathrm{M}$ & 0.5 & 0.1 & & Cortex & LV & Insertion & $\mathrm{RD} \ddagger$ \\
\hline 9 & $74 / \mathrm{F}$ & 0.6 & 1.0 & & Cortex & PPV & Insertion & \\
\hline 10 & $65 / \mathrm{F}$ & 0.3 & 1.0 & & Cortex & PPV & Insertion & \\
\hline 11 & $50 / \mathrm{M}$ & 0.7 & 1.2 & & Cortex & PPV & Insertion & \\
\hline 12 & $71 / \mathrm{F}$ & 0.5 & 1.0 & & Cortex & LV & Insertion & \\
\hline 13 & $87 / \mathrm{F}$ & 0.1 & 1.0 & Small pupil & Cortex & LV & Suture & \\
\hline 14 & $68 / \mathrm{F}$ & 0.6 & 0.6 & & Nucleus & LV & Insertion & $\mathrm{CMO} \ddagger$ \\
\hline 15 & $49 / M$ & 0.2 & 0.9 & & Nucleus & PPV & Insertion & Luxation of IOL $\ddagger$ \\
\hline 16 & $68 / M$ & 0.4 & 0.2 & Small pupil, DMR & Nucleus & PPV & Insertion & CMO $\ddagger$, OHT $\ddagger$ \\
\hline 17 & $87 / M$ & 0.01 & 0.4 & & Cortex & PPV & Suture & \\
\hline
\end{tabular}

$\mathrm{DMR}=$ diabetic retinopathy; PPV = three port pars plana vitrectomy; LV = three port limbal based vitrectomy; suture = intraocular lens (IOL) sutured to sclera; insert $=$ IOL placed upon anterior capsule; $\mathrm{RD}=$ retinal detachment; $\mathrm{PC}=$ photocoagulation; $\mathrm{CMO}=$ cystoid macular oedema; OHT = ocular hypertension within 1 week after operation.

^Decimal.

$\dagger$ Intraoperative complications.

$\ddagger$ Postoperative complications.

16). Both were well controlled with medication and it was discontinued within a week.

Corneal endothelial cells were counted in 15 eyes $(88 \%)$. The endothelial cell loss in the complication and no complication groups were $5.7 \%$ (SD $6.8 \%$ ) and $5.3 \%(7.4 \%)$, respectively; the difference was not statistically significant $(p=0.7664)$. Final visual acuity was 0.5 or better in 14 eyes ( $82 \%$ ), and $0.4-0.1$ in three eyes $(18 \%)$.

\section{Discussion}

The incidence of dislocation of lens fragments into the vitreous cavity during PEA was $0.20 \%$ in the present study, in accord with previous reports. ${ }^{78}$ Postoperative retinal detachment was observed in two patients $(12 \%)$ in our series. The cumulative rate of retinal detachment after vitrectomy for retained lens fragments was calculated as $9 \%(56 / 616)$ by Monshizadeh et al. ${ }^{9}$ Our results confirmed considerable risk of retinal detachment even when the fragments were removed at the time of PEA.

Postoperative cystoid macular oedema, reported to occur in up to $27 \%$ in patients undergoing vitrectomy with retained intravitreal lens material, ${ }^{1-4} 6$ developed in two $(12 \%)$ of our patients (Table 2). Secondary glaucoma, reported in $13-41 \%$ in patients undergoing

Table 2 Visual results and postoperative complications for reported patients with retained lens fragments

\begin{tabular}{|c|c|c|c|c|c|c|}
\hline & & & $\begin{array}{l}\text { Visual acuity } \\
20 / 40 \text { or better }\end{array}$ & $\begin{array}{l}\text { Retinal detachment } \\
\text { after vitrectomy }\end{array}$ & $\begin{array}{l}\text { Cystoid macular } \\
\text { oedema }\end{array}$ & $\begin{array}{l}\text { Secondary } \\
\text { glaucoma }\end{array}$ \\
\hline Series & Year & eyes & No (\%) & No (\%) & No (\%) & No (\%) \\
\hline Gilliland $^{1}$ & 1992 & 56 & $28(50)$ & $4(7)$ & $3(5)^{\star}$ & $14(25) \subseteq$ \\
\hline $\mathrm{Kim}^{2}$ & 1994 & 62 & $42(68)$ & $2(3)$ & 7 (11) & $8(13)$ \\
\hline Borne $^{3}$ & 1996 & 121 & $82(68)$ & $11(9)$ & $4(3) t$ & - \\
\hline Margherio $^{4}$ & 1997 & 126 & $56(44)$ & $13(10)$ & $34(27)$ & $32(25) \Omega$ \\
\hline $\mathrm{Yeo}^{6}$ & 1999 & 22 & $13(59)$ & $1(5)$ & $0(0)$ & $9(41) \ddagger$ \\
\hline Current study & 2001 & 17 & $14(82)$ & $2(12)$ & $2(12)$ & $0(0)$ \\
\hline
\end{tabular}

${ }^{\star}$ Includes only patients with visual acuity $20 / 200$ or worse.

†Includes only patients with visual acuity counting fingers or worse.

$\ddagger$ Intraocular pressure (IOP) $>20 \mathrm{~mm} \mathrm{Hg}$.

\$IOP $>25 \mathrm{~mm} \mathrm{Hg}$

शIOP $>30 \mathrm{~mm} \mathrm{Hg}$. vitrectomy to remove lens fragments, ${ }^{12} 46 \mathrm{did}$ not develop in any of the eyes that we treated (Table 2). Kim et al also reported that glaucoma did not develop in any of their eight patients undergoing vitrectomy at the time of cataract surgery. ${ }^{2}$ Our ability to minimise incidence of secondary glaucoma supports previous reports concluding that early vitrectomy can lower the risk of secondary glaucoma. ${ }^{6}{ }^{10} 11$ Visual prognosis was also favourable compared to those in previous reports (Table 2). In our group only two eyes had pre-existing posterior segment diseases such as diabetic retinopathy, which may explain in part our success in converting from PEA to vitrectomy.

Corneal endothelial cell damage in eyes undergoing vitrectomy for intravitreal lens material has not been previously studied to our knowledge. There was no statistically significant difference between the complication and no complication groups although eyes with complicated PEA and vitrectomy are supposed to have more corneal endothelial cell damage than those with uncomplicated surgery owing to excessive intraocular manipulations.

In summary, the incidence of postoperative complications was no greater than in earlier studies and no patients developed glaucoma. Corneal endothelial cell loss was slight, similar to that with PEA only. Our results showed better consequence, indicating the possible advantage of primary vitrectomy to prevent them by removing the retained lens material which may cause persistent uveitis. ${ }^{261011}$ Being retrospective, our study was not conclusive. None the less our results suggest simultaneous vitrectomy with careful manipulation may be beneficial to minimise the complications caused by retained lens material. Fewer floaters and eliminating the need for two separate operations are also to the patients' advantage. Hence, when vitreoretinal surgeons are readily available, we recommend that simultaneous vitrectomy with IOL implantation at the time of PEA complicated by intravitreal lens material. 
None of the authors has a financial or proprietary interest in any material or method mentioned.

1 Gilliland GD, Hutton WL, Fuller DG. Retained intravitreal lens fragments after cataract surgery. Ophthalmology 1992;99:1263-7.

2 Kim JE, Flynn HW Jr, Smiddy WE, et al. Retained lens fragments after phacoemulsification. Ophthalmology 1994;101: ments after

3 Borne MJ, Tasman W, Regillo C, et al. Outcomes of vitrectomy for retained lens fragments. Ophthalmology 1996;103 971-6.

4 Margherio RR, Margherio AR, Pendergast SD, et al. Vitrectomy for retained lens fragments after phacoemulsification. Ophthalmology 1997;104:1426-32.

5 Tommila P, Immonen I. Dislocated nuclear fragments after cataract surgery. Eye 1995;9:437-41.
6 Yeo LM, Charteris DG, Bunce C, et al. Retained intravitreal eo LM, Charteris DG, Bunce C, et al. Retained intravitreal lens fragments after phacoemulsification: a clinicopa
logical correlation. Br f Ophthalmol 1999;83:1135-8.

7 Leaming DV. Practice styles and preferences of ASCRS members-1994 survey. F Cataract Refract Surg 1995;21: 378-85.

8 Pingree MF, Crandall AS, Olson RJ. Cataract surgery complications in 1 year at an academic institution. $\mathcal{F}$ Cataract Refract Surg 1999;25:705-8.

9 Monshizadeh R, Samiy N, Haimovici R. Management of retained intravitreal lens fragments after cataract surgery. Surv Ophthalmol 1999;43:397-404.

10 Blodi BA, Flynn HW Jr, Blodi CF, et al. Retained nuclei after cataract surgery. Ophthalmology 1992;99:41-4.

11 Fastenberg DM, Schwartz PL, Shakin JL, et al. Management of dislocated nuclear fragments after phacoemulsification. Am f Ophthalmol 1991;112:535-9.

\section{7th European Forum on Quality Improvement in Health Care}

\section{1-23 March 2002 \\ Edinburgh, Scotland}

We are delighted to announce this forthcoming conference in Edinburgh. Authors are invited to submit papers (call for papers closes on Friday 5 October 2001) and delegate enquiries are welcome.

The themes of the Forum are:

- Leadership, culture change, and change management

- Achieving radical improvement by redesigning care

- Health policy for lasting improvement in health care systems

- Patient safety

- Measurement for improvement, learning, and accountability

- Partnership with patients

- Professional quality: the foundation for improvement

- Continuous improvement in education and training

- People and improvement.

Presented to you by the BMJ Publishing Group (London, UK) and Institute for Healthcare Improvement (Boston, USA). For more information contact: quality@bma.org.uk or look at the website www.quality.bmjpg.com. Tel: +44 (0)20 7383 6409; fax: +44 (0)20 73736869 . 